\section{Management of a Dormitory Library}

Some of the details of handling an ancillary student collection are here treated by the classifier at the University of Kansas Library.

$\mathrm{T}$ HE ARRANGEMENT and administration of a dormitory library at the University of Kansas have occasioned the development of a system of classification that may be of interest to librarians elsewhere. The scheme is a modification of the Dewey system adapted to the needs of an extracurricular reading library with a few background books. The library with which this paper deals is in Carruth Hall, one of the four cooperative dormitories for men. It serves all four dormitories, although each of the other three has a small book collection of its own. As it is a memorial library, all the books have been gifts or purchases from a gift fund. ${ }^{1}$ The library is entirely independent of the university library but is administered by a committee consisting of one member of the department of English, an interested alumna who is the wife of a faculty member, the librarian of the bureau of general information, and the classifier of the university library. This committee works in cooperation with the student librarian.

1 The library is the Alberta Linton Corbin Memorial Library. It was established after her death by friends of Miss Corbin, to carry out her expressed wish that books be provided for the Carruth Hall Library. During books be provided for the Carruth Hall Library. During and later a colleague of William Herbert Carruth for wbom the hall is named. Books from the private libraries of Miss Corbin and of Mr. Carruth form a part of the present collection.
In developing plans for the arrangement and administration of the library, publications of numerous authorities were consulted. Excellent material is available on the general question of dormitory and fraternity libraries and book selection, but little has been written on the subject of arrangement. This is probably due to the fact that most of the collections described are selected and administered by college or university libraries. Thus the dormitory library, and sometimes the fraternity library, functions somewhat like a branch or depository library.

Branscomb $^{2}$ in his Teaching with Books includes an informative chapter on the general question of dormitory libraries, with emphasis on "course" libraries. Carnovsky" has written of the same type of library at the University of Chicago, and Morgan ${ }^{4}$ regarding it at Harvard. As to arrangement, Carnovsky says: "The books were not classified. They were arranged on the shelves in several large and general groups: reference books; the optional readings of the four general courses, each course represented in its own section; poetry; drama; fiction; and general nonfiction. Within each group the books were shelved alphabetically by author." At the time Morgan

2 Branscomb, Bennett Harvie. "Books in Halls of Residence." In his Teaching with Books, p. 147-65. Chicago, A.L.A. I940.

3 Carnovsky, Leon. "Dormitory Library: an Ex. periment in Stimulating Reading." Library Quarterly 3:37-65, January 1933 .

"Morgan, Kenneth. "The Harvard House Libraries." Library Journal 56:536-39, June 15, 1931. 
wrote his article, Harvard had tried the L.C. classification unsuccessfully for the house libraries and had decided to work out a scheme of its own. An example of the other type of dormitory library-the "reading for fun" library-is the Stephens College plan as described by Johnson. ${ }^{5,6}$ But this again is administered through the college library.

Material on fraternity libraries is interesting but did not quite meet our needs, although our library is similar to a large fraternity library and has many of the same problems. Drury ${ }^{7}$ supplies essential information for the smaller library of this kind in his article "The Library in the Fraternity House." This gives a list of basic books, references to other book lists available at the time, and suggestions for a simple classification and for administration. Huntington's paper $^{8}$ on fraternity house libraries at the University of Illinois contains suggestions for a small library. Onthank ${ }^{9}$ and Lewis ${ }^{10}$ treat of collections lent by the college library to dormitories and fraternities. All of these articles were helpful in various ways but not satisfying on the question of arrangement.

\section{Beginnings of Library}

When we began to organize the library, there were about one thousand volumes. A gift of over six hundred volumes from $\mathrm{Mr}$. and Mrs. William Allen White in 194I formed the nucleus of the collection. Gifts

5Johnson, B. Lamar. "Dormitory Libraries." In his Vitalizing a College Library, p. 54-64. Chicago, A.L.A., 1939 .

Johnson, B. Lamar. "Dormitory Libraries at Stephens College." Library Quarterly 5:215-31, April 1935 .

House." Peabody Journal of Education January 2935.

8 Huntington, Lucile. "Fraternity House Libraries at the University of Illinois." Library Journal 63 : 730-33, Oct. I, 1938 .

"Onthank, K. W. "Fraternity Circulating Libraries." Wilson Library Bulletin 11:394-96, February 1937 .

bewis, W. P. "Dormitory and Fraternity Liber 1935. from various individuals, subscriptions to book clubs, and purchases from the gift fund constifuted the rest. When the White collection arrived, a "finding list" was made on cards. This information included the author, brief title, and date. For a time this list was the only record kept, and the books were placed on the shelves with no particular arrangement. When the demand arose for some sort of grouping, the committee was formed to consider the question. Student assistants were available without cost, since each resident of a cooperative dormitory is required to work from nine to fourteen hours a week. The classifier of the university library worked out the classification scheme, presented at the end of this paper, mainly on a trial-and-error basis depending on the number of books in the group. The Dewey classification was selected as the foundation because it is used in the university library. The committee felt that if numbers could be omitted from the backs of books, the informal home atmosphere would be favored. This omission has worked out satisfactorily.

The finding list was used as a basis for the catalog. Later, title cards were added and shelf-list cards were made. A manual was prepared for the use of the student librarian who worked under the supervision of the university library classifier. Two extra copies were made, one for the university collection and one to be lent to other dormitories and fraternities.

The first part of the manual contains a history of the library and newspaper clippings concerning it. The next section is devoted to supplies. Names of library supply companies and a list of essential equipment are included, with the information that catalogs of the companies may be consulted at the office of the director of university libraries or may be secured from the company. Following this is the main 
part, outlining the duties of the librarian, which include acknowledging all gifts in writing; preparing books for the shelves; cataloging and shelflisting; taking inventory and recording lost and discarded books; and explaining rules, use, and history of the library.

Instructions for making author, title, shelflist, and guide cards are given in detail, with sample cards. The classification scheme, with instructions and explanations, forms a large part of this division. A copy of the Dewey's Abridged Decimal Classification is kept in the library, and the librarian is urged to consult the tables and index for help. $\mathrm{He}$ is instructed to classify books before or at the same time the cataloging is done, so that the number may be included on the cards and written in the book without an extra operation.

In the division on rules and use are instructions for charging and returning books. A charging book is provided, in which the student borrower signs his name, the author and title of the book taken, and the date. No length of time is set for keeping books out, but the librarian is instructed to go through the charging record occasionally and call in any that have been on loan for an unreasonable period. Books are returned to a shelf marked "Return books here." The librarian cancels the charges and shelves the books.

The last section of the manual is given over to miscellaneous material: sample bookplates, lists of special collections, and anything else that should be preserved in the records. All instructions are given in an elementary manner so that untrained students may understand and administer the library with a minimum of supervision. Two years have passed since its organization, but in spite of the vicissitudes of the times, with rapidly changing personnel, the library is functioning smoothly and effectively.

The classification scheme, as used and as set forth in the manual, is as follows:

200 Philosophy. Ethics. Religion. 200 includes books that would classify in the Dewey scheme in 10o. We have combined 100 and 200 under 200.

300 Social questions.

320 Political science and government.

327 Foreign relations. Diplomacy. Peace. War. (General. Special wars go in history)

330 Economics. Labor. Business.

600 Science. Health.

Books which would class in the Dewey 500 go here, since we have combined 500 and 600 under 600 .

700 Fine arts: Art. Architecture. Music. 790 Sports. Hobbies. Amusements.

800 Class all literature here except:
8I I Poetry
812 Drama
Fiction (no number)
M Mysteries

900 History.

Class all history here except World War I and II (940) and U.S. (973)

910 Description and travel.

B Biography.

B (alone) collections (Shelve 9ro and B before 900 in order to keep history together)

$\mathrm{B}$ as $\mathrm{B}$ for individual name Lincoln

940 World Wars I and II.

973 U.S. and state history.

$\mathrm{R}$ Reference books: encyclopedias, dictionaries, statistics, etc.

T Textbooks. 